\title{
African Swine Fever: Penyakit Emerging yang Mengancam Peternakan Babi di Dunia
}

\section{(African Swine Fever: An Emerging Disease Threatening Pig Farms in The World)}

\author{
Indrawati Sendow, A Ratnawati, NLPI Dharmayanti dan M Saepulloh \\ Balai Besar Penelitian Veteriner \\ Kontributor utama: Indrawati Sendow; alamat email: indrawati.sendow@yahoo.com
}

(Diterima 5 Desember 2019 - Direvisi 20 Februari 2020 - Disetujui 13 Maret 2020)

\begin{abstract}
African swine fever (ASF) is a highly infectious disease in pigs that caused by the double-stranded DNA virus of the Asfarviridae family. The disease is characterized by haemorrhages in the ears, back and legs. This virus causes death in pigs and has a large economic impact. However, ASF is not a zoonotic disease, hence it has no an impact on human health. This paper will discuss about ASF disease, route of transmision, how to diagnose, and handling of ASF. This disease has spread throughout Asia in a relatively short time in 2019, and this exotic disease has been reported entering Indonesia at the end of 2019. There is no effective prevention and control of the disease. Several vaccines have been developed but are still considered ineffective while commercial vaccines are not yet available. Safety and effectiveness of vaccines are still being considered because ASF virus is very unique and different from other DNA viruses, Therefore, prevention of ASF infection should be done by conducting strict biosecurity, applying regulations on the movement of pigs and pig products to the region or country.
\end{abstract}

Key words: African Swine Fever, characteristic, transmission, control, swill feeding

\section{ABSTRAK}

African swine fever (ASF) merupakan penyakit infeksius pada babi yang disebabkan oleh virus DNA beruntai ganda dari family Asfarviridae. Penyakit ini umumnya ditandai dengan perdarahan pada telinga, punggung dan kaki. Virus ini menyebabkan kematian dan mempunyai dampak ekonomi yang besar, namun penyakit ASF tidak bersifat zoonosis sehingga tidak menimbulkan dampak bagi kesehatan manusia. Penyakit ini telah menyebar ke seluruh Asia dalam waktu yang relatif singkat pada tahun 2019, bahkan telah dilaporkan penyakit ini masuk ke Indonesia sejak akhir tahun 2019. Tulisan ini membahas penyakit ASF, cara penularan, cara diagnosis dan penanganannya. Pencegahan yang efektif dan kontrol penyakit ASF belum ada. Beberapa jenis vaksin telah dikembangkan namun vaksin tersebut dinilai tidak efektif sedangkan vaksin komersial belum tersedia. Keamanan dan efektivitas vaksin masih harus dipertimbangkan karena sifat virus ASF yang sangat unik dan berbeda dengan virus DNA lainnya Oleh karena itu, pencegahan penyakit ASF harus dilakukan dengan melakukan biosekuriti yang ketat, menerapkan regulasi tentang lalu lintas babi dan produk babi ke suatu wilayah atau negara.

Kata kunci: African Swine Fever, karakteristik, penularan, pencegahan, swill feeding

\section{PENDAHULUAN}

African swine fever (ASF) atau dikenal dengan demam babi Afrika merupakan penyakit infeksius pada babi bersifat hemoragik yang disebabkan oleh virus DNA beruntai ganda, dalam family Asfarviridae dan genus Asfivirus. Virus ini menyebabkan demam berdarah dengan tingkat kematian yang tinggi pada babi domestik dan babi liar. African swine fever (ASF) pertama kali dilaporkan di Kenya pada tahun 1920 (Montgomery 1921) dan saat ini ASF telah menyebar ke Asia termasuk Indonesia.

Penyakit ASF ditularkan melalui gigitan kutu caplak (Ornithodorus sp) yang terinfeksi, sehingga penyakit ini dikategorikan dalam arthropod borne disease (Boinas et al. 2011). Penyakit ASF tidak bersifat zoonosis sehingga tidak menimbulkan risiko terhadap kesehatan manusia, tetapi mempunyai dampak ekonomi yang sangat signifikan bagi peternak babi di dunia karena morbiditas dan mortalitasnya yang tinggi. Dampak penyakit ASF juga dirasakan pada industri pakan babi dan pemasok bahan baku pakan seperti yang terjadi di China. Oleh karena itu, penyakit ini termasuk dalam daftar OIE notifiable disease dan juga dapat termasuk dalam bioterror untuk menghancurkan kondisi ekonomi di suatu wilayah dengan populasi babi tinggi dan peternak yang hanya mengandalkan mata pencarian dari beternak babi.

Penyebaran virus ASF dapat melalui lalu lintas ternak dan produk babi yang tercemar melalui swill feeding, yang digunakan untuk pakan ternak sehingga penyakit ini dapat menyebar dengan cepat ke beberapa 
negara sehingga penyakit ASF ini termasuk penyakit lintas batas (transboundary animal diseases) (BeltránAlcrudo et al. 2019).

Mengingat penyakit ini merupakan penyakit yang baru masuk di Indonesia tahun 2019, maka peternak babi dan petugas terkait perlu mengetahui tentang penyakit ASF sehingga dapat segera mengambil tindakan cepat jika penyakit ini muncul. Tulisan ini akan membahas mengenai penyakit ASF, cara penularan, epidemiologi, diagnosis dan pencegahannya.

\section{KARAKTERISTIK VIRUS ASF}

Penyakit ASF disebabkan oleh virus ASF, yang merupakan virus DNA beruntai ganda genus Asfivirus. Hingga saat ini virus ASF hanya memiliki satu serotipe meskipun terdapat 23 genotipe dengan virulensi yang bervariasi (Rodriguez et al. 2015). Meskipun virus ASF mempunyai satu serotipe, namun penelitian terakhir menyatakan bahwa virus ASF dapat dikelompokkan menjadi 8 serogroup berdasarkan hemadsorption inhibition assay (HAI) pada biakan jaringan. Adanya hemadsorption, merupakan patognomonik adanya virus ASF yang membedakan dengan virus Classical Swine Fever (CSF) (Malogolovkin et al. 2015).

Virus ASF sangat tahan terhadap perlakuan fisik seperti beku cair, ultrasonografi dan suhu rendah, namun dengan pemanasan $56^{\circ} \mathrm{C}$ selama 70 menit dan $90^{\circ} \mathrm{C}$ selama 30 menit, virus ini akan inaktif. Penyimpanan virus ASF pada suhu $-80^{\circ} \mathrm{C}$ dapat bertahan selama bertahun-tahun, sedangkan pada suhu $20^{\circ} \mathrm{C}$ bertahan hingga 65 minggu. Virus ini juga tahan terhadap beberapa bahan kimia seperti tripsin dan EDTA (Ethylene Diamine Tetraacetic Acid). Virus ASF dalam darah (viraemia) yang disimpan dalam keadaan dingin dapat bertahan selama 75 minggu, sedangkan pada medium transport dapat bertahan selama 12 hari. Oleh karena itu, transportasi sampel lapang harus mengikuti sistem rantai dingin agar virus tetap hidup. Virus ini juga tidak tahan hidup dalam kondisi antara $\mathrm{pH} 3,9$ hingga 13,4 . Berdasarkan sifat kimianya, virus ini akan inaktif terhadap eter, kloroform, natrium hidroksida, hipoklorit, 0,5\% klorin, 3/1000 formalin selama 30 menit, 3\% orthophenylphenol selama 30 menit dan senyawa yodium (Mazur-Panasiuk et al. 2019b; OIE 2018)

Virus ASF dapat bertahan hidup dalam jangka waktu lama dalam darah, feses dan jaringan, produk daging babi mentah atau kurang matang. Virus ASF dapat terdeteksi pada daging dengan dan tanpa tulang dan daging giling selama 105 hari, pada daging yang diasinkan 182 hari, daging yang diasap 30 hari, daging yang dimasak (minimal 30 menit pada $70^{\circ} \mathrm{C}$ ) 0 hari, daging kering 300 hari, daging dalam keadaan dingin 110 hari, daging beku 1.000 hari, jeroan babi 105 hari, kulit/lemak (bahkan dikeringkan) 300 hari, darah disimpan pada suhu $4^{\circ} \mathrm{C} 18$ bulan, kotoran pada suhu kamar 11 hari, darah membusuk 15 minggu dan kandang babi yang terkontaminasi 1 bulan. (BeltránAlcrudo et al. 2017: Mazur-Panasiuk et al. 2019b). Sedangkan pada pinjal berkulit lunak (soft ticks) seperti Ornithodoros erraticus dapat bertahan hingga 5 tahun. Sementara itu, umur O. erraticus dapat mencapai 20 tahun (Boinas et al. 2011).

Virus ASF merupakan virus yang sangat unik, hidup dalam makrofag darah sehingga antibodi yang ditimbulkan tidak cukup untuk menetralkan virus sehingga penggunaan vaksin masih belum efektif (Dixon et al. 2013). Hal ini berbeda dengan virus Hog Cholera atau Classical Swine Fever, dimana virus CSF dapat menetralkan antibodi yang ditimbulkan dan tidak mempunyai kemampuan hemadsoption (SánchezVizcaíno et al. 2015). Pengobatan dan pencegahan penyakit ASF melalui vaksinasi sampai saat ini belum tersedia. Vaksin ASF telah dikembangkan baik konvensional hingga molekuler, namun tidak memberikan hasil yang memuaskan dan kurang efektif.

Epidemiologi molekuler infeksi virus ASF berdasarkan perubahan pada gen atau penanda genetik sering dilakukan. Gen imunomodulator protein virus ASF dapat digunakan untuk mempelajari keragaman dan dinamika evolusi virus ASF seperti filogenetik dari protein imunomodulator virus ASF 5EL (Gen A238L), I14L (gen Dp71L) dan K11L (gen I329L) serta memprediksi virulensi virus ASF. Karakterisasi protein tersebut dapat digunakan untuk pengembangan vaksin ASF (Nefedeva et al. 2019).

Babi yang terinfeksi ASF dan sembuh dapat menjadi karier dan bersifat kronis. Hal ini juga dikemukakan oleh Abworo et al. (2017) yang menunjukkan bahwa di Uganda, 15,9\% populasi babi sehat di daerah endemis ASF mengandung virus ASF pada organ tetapi negatif pada darah dengan uji PCR dan dengan uji ELISA. Hal ini menunjukkan bahwa babi tersebut dapat bertindak sebagai karier. Berdasarkan data tersebut diasumsikan bahwa babi karier dapat berperan dalam memelihara virus ASF dalam tubuh dan jika babi mengalami stres akibat transportasi dapat menimbulkan wabah berkesinambungan, sehingga ASF sulit untuk diberantas. Oleh karena itu, pemberantasan penyakit ini dilakukan dengan pemusnahan babi yang kontak dengan yang sakit atau babi yang telah sembuh meskipun tidak menunjukkan gejala klinis. Adanya kasus ko-infeksi dengan patogen lain dapat menyebabkan salah satu faktor menyebabkan virus ASF terekskresi atau laten. Lebih lanjut, Mur et al. (2016) mengemukakan bahwa antibodi terhadap virus ASF dapat terdeteksi pada babi liar yang tidak menunjukkan gejala klinis walaupun telah terinfeksi dan virus bersirkulasi pada babi liar tersebut atau 
menjadi karier yang dapat menularkan ke babi lainnya sehingga menimbulkan penyakit.

\section{JALUR PENULARAN}

Penularan penyakit ASF dapat terjadi melalui kontak langsung maupun tidak langsung dan melalui gigitan kutu caplak (Ornithodorus sp) yang telah mengandung virus ASF. Penularan secara kontak langsung melalui cairan tubuh hewan yang terinfeksi seperti air liur, sekresi pernapasan, urin dan feses, sedangkan kontak tidak langsung melalui fomit atau benda-benda lain yang tercemar virus ASF termasuk pemberian pakan sampah (swill feeding) baik dari pesawat maupun restoran yang mengandung daging babi yang tercemar virus ASF, kendaraan pengangkut babi yang terinfeksi, pakaian dan peralatan makan babi yang telah tercemar virus ASF dan melalui lalu lintas babi sakit (Kipanyula \& Nong’ona 2017).

Beberapa spesies caplak Ornithodorus sp yang telah dilaporkan bertindak sebagai penular ASF diantaranya O. erraticus (O. marocanus), O. moubata complex, O. puertoricensis, O.coriaceus, O. turicata, O. savignyi, O. sonrai. (OIE 2017).

Faktor utama penyebab terjadinya siklus penularan ASF di Afrika adalah populasi babi yang tinggi, sistim peternakan ekstensif dan biosekuriti yang tidak ketat serta penggunaan swill feeding sebagai pakan babi (Penrith et al. 2013). Masuknya ASF ke China dilaporkan juga melalui jalur transportasi seperti truk, pesawat dan kapal laut pengangkut makanan yang terkontaminasi virus ASF, lalulintas ternak babi dan babi liar baik secara legal maupun ilegal, barang impor ilegal/ barang bawaan yang terdiri dari makanan, produk daging babi yang terkontaminasi virus ASF baik untuk konsumsi pribadi atau komersial ( FAO 2018).

Mengingat cepatnya penyebaran ASF di Asia dalam beberapa bulan terakhir ini, maka pengawasan di bandara dan pelabuhan yang banyak wisatawan asing terutama dari negara tertular perlu mendapat pengawasan yang lebih ketat terutama di perbatasan wilayah dengan negara tertular. Sebagian besar wisatawan dari negara tertular sering membawa makanan sendiri yang mengandung daging babi dan produknya yang telah terkontaminasi sehingga dikuatirkan dapat membawa virus ASF dalam produk makanan tersebut.

Jalur penularan ASF lainnya adalah melalui rantai penjualan babi di pasar seperti rendahnya tingkat kesadaran dan pengetahuan akan penyakit ASF seperti gejala klinis, cara transmisi ASF diantara peternak babi dan pedagang; sebagian besar peternak kecil sering menjual babi yang sakit atau langsung memotong babi tanpa pemeriksaan kesehatan babi terlebih dahulu, sulitnya pengawasan lalu lintas ternak babi antar lokasi atau daerah (Siamupa et al. 2017). Olesen et al (2017) dalam penelitiannya membuktikan bahwa kontak langsung dengan babi sakit dan aerosol merupakan jalur penularan ASF paling efektif.

Hasil penelitian Mazur-Panasiuk \& Woźniakowski (2019a) menunjukkan bahwa kejadian wabah ASF di Polandia akibat pergerakan manusia dari daerah terinfeksi ke daerah bebas. Program pengendalian ASF dapat dilakukan melalui sosialisasi tentang ASF dan rute penularan penyakit serta pencegahannya, terutama di kalangan peternak yang kurang menerapkan biosekuriti (Chenais et al. 2019).

\section{PERAN SWILL FEEDING DALAM PENYEBARAN PENYAKIT ASF}

Sebagai penyakit lintas batas (transboundary animal disease), faktor manusia sangat berperan dalam menyebarkan penyakit ASF dari suatu negara ke negara lain. Sebagai contoh adalah penggunaan swill feeding dari pesawat atau kapal yang telah tercemar ASF dan digunakan sebagai pakan oleh peternak babi. Situasi seperti ini dilaporkan oleh Kipanyula \& Nong'ona (2017), bahwa penyebaran infeksi ASF lebih banyak melalui kendaraan pengangkut dan manusia yang membawa swill feed untuk pakan babi.

Swill feeding diartikan sebagai sampah dalam bentuk sisa-sisa makanan baik yang berasal dalam negeri maupun dari luar negeri. Swill feeding dalam negeri berupa sisa makanan dari kafe, restoran, klub, Rumah sakit, panti jompo, kantin sekolah, klub olahraga, tempat pemotongan daging, tempat pembuatan roti, supermarket, hotel, supermarket, outlet makanan 'takeaway', rumah tangga, pasar dan pabrik sosis dalam negeri. Sedangkan swill feeding yang berasal dari luar negeri/internasional dapat berupa sisa katering pesawat udara dan kapal laut dengan trayek luar negeri, atau barang sitaan berupa makanan yang mengandung daging babi dan produknya (Penrith et al. 2013).

Swill feeding seharusnya dibuang/dimusnahkan dan dilakukan pengolahan limbah sampah, namun yang terjadi saat ini sisa makanan tersebut sering digunakan sebagai bahan pakan ternak karena harga yang relatif murah dibanding dengan pakan ternak komersial sehingga umumnya swill feeding untuk pakan ternak banyak dimanfaatkan oleh peternak tradisional. Beberapa kejadian penyakit ASF akibat penggunaan swill feeding di luar negeri telah banyak dilaporkan (Penrith et al. 2013; FAO 2018). Oleh karena itu untuk negara yang telah positif ASF sebaiknya dilarang menggunakan swill feeding yang mengandung atau berasal dari pemrosesan produk babi.

Laporan Zhou et al. (2019) menunjukkan bahwa masuknya ASF di beberapa negara di Eropa dan Asia melalui pemasukan daging babi mentah dan produk 
olahan baik secara legal maupun ilegal, serta swill feeding yang berasal dari pesawat atau kapal laut. Lebih lanjut, lalu lintas babi liar yang terinfeksi juga dilaporkan sebagai penyebar infeksi ASF di Rusia padaa tahun 2008 (Beltran-Alcrudo et al. 2019).

Meskipun demikian, tidak semua swill feeding berpotensi sebagai penyebar penyakit. Pada kasus ASF, hanya swill feeding yang mengandung daging babi dan produk daging babi yang tercemar virus ASF mempunyai potensi meyebarkan ASF dan dapat menyebabkan risiko tinggi masuknya ASF ke suatu negara.

Apabila ASF sudah masuk ke suatu negara menyebabkan sulit untuk melakukan pemberantas apabila telah menyebar luas, kecuali jika segera dilakukan stamping out pada peternakan tersebut sebelum sempat tersebar. Disamping itu, komitmen yang sangat kuat dari pemegang kebijakan dan semua stake holder yang terlibat diperlukan untuk mencegah penyebaran lebih meluas.

\section{DIAGNOSIS ASF}

Diagnosis ASF dapat didasarkan pada pengamatan gejala klinis, pengamatan epidemiologi penyakit, pemeriksaan laboratorium, baik uji serologi, virologis maupun pemeriksaan post mortem. Uji virologis yang cepat dan akurat sangat diperlukan untuk penanganan infeksi ASF.

\section{Manifestasi klinis ASF}

Manifestasi infeksi ASF menghasilkan 4 bentuk gejala klinis seperti perakut, akut, subakut dan kronis, tergantung dari virulensi strain yang menginfeksi, strain babi dan status kekebalan (Sanchez-Vizcano et al. 2015). Umumnya, babi liar seperti babi hutan lebih rentan terhadap infeksi ASF dan tidak menimbulkan gejala klinis yang khas, namun dapat bertindak sebagai karier virus ASF (Cabezón et al. 2017).

Tanda-tanda klinis bervariasi berdasarkan jenis virus dan bentuk penyakit yang disebabkan oleh virus. Bentuk perakut ASF pada babi perakut-menyebabkan kematian sangat cepat dan tiba-tiba, sering menjadi indikasi awal penyakit. Penyakit ASF bentuk akut menyebabkan demam mencapai $40,5-42^{\circ} \mathrm{C}$, anoreksia, lesu, sianosis, inkoordinasi, peningkatan nadi dan laju pernapasan, erithrema pada sekitar telinga dan badan babi (Sanchez-Vizcano et al. 2015; Titov et al. 2017), diare, muntah, batuk dan sesak nafas, leukopenia dan trombositopenia (pada 48-72 jam), muntah, diare dan abortus (Chenais et al. 2017; Sánchez-Vizcaíno et al. 2015).

Pada kasus wabah ASF pertama di Tanzania, gejala klinis yang muncul antara lain demam tinggi, depresi, ketidakseimbangan, mukosa pucat, pendarahan, lesi eritematosa di berbagai bagian tubuh dan abortus. Beberapa organ dalam termasuk ginjal, limpa, dan hati padat dan edematous dengan mortalitas mencapai 100\% (Kipanyula \& Nong Ona. 2016). Pada kasus wabah ASF ke dua kematian babi menurun hingga 50\%. Gejala klinis yang klasik lebih banyak ditemukan pada kasus ASF pertama, sedangkan kasus berikutnya jarang nampak, bahkan dapat tidak menimbulkan gejala meskipun kelainan patologis di organ hati, limpa masih dapat ditemukan (Kipanyula \& Nong'ona 2017; Sanchez-Vizcano et al. 2015).

Babi yang terinfeksi ASF bentuk subakut, menunjukkan gejala klinis seperti demam ringan, nafsu makan hilang, dan depresi, kadang disertai dengan abortus pada babi bunting. Babi terinfeksi bentuk kronis menunjukkan nafsu makan tidak ada, tidak demam atau suhu normal, pernapasan cepat, nekrosis kulit, borok kulit kronis dan pembengkakan sendi. Masa inkubasi bervariasi berdasarkan rute penularan, berkisar 3-21 hari (Balyshev et al. 2018). Kedua bentuk ini jarang terjadi atau sulit terdeteksi dibanding bentuk perakut dan akut.

Semua tipe penyakit ASF tersebut mempunyai angka morbiditas yang tinggi, tetapi mortalitasnya bervariasi tergantung tipe penyakitnya. Bentuk perakut, mortalitas mencapai $100 \%$ setelah 7-10 hari pasca infeksi, bentuk akut mortalitas mendekati $100 \%$ setelah 6-13 hari pasca infeksi, bentuk subakut mortalitas bervariasi tergantung umur babi, sedangkan bentuk kronis, mortalitasnya rendah. (Balyshev et al. 2018). Mortalitas penyakit ASF pada babi muda lebih tinggi (70-80\%) dibandingkan babi tua (kurang dari 20\%).

Diagnosis ASF disamping melihat gejala klinis, pemeriksaan patologis anatomis juga sering dilakukan pada saat bedah bangkai pada babi yang telah mati atau dibunuh. Hasil nekropsi pada babi yang mati menunjukkan kelainan pada organ seperti eritrema pada kulit, edema paru limpa membengkak dan hepiremi sehingga warna limpa menjadi hitam, hati bengkak, terdapat cairan pada pericard dan sering ditemukan ptechie atau haemorrhages pada jantung, ginjal, dan limphonodul (Sanchez-Vizcano et al. 2015; Kipanyula \& Nong'ona 2017)

Penyakit ASF sering dikelirukan dengan penyakit lainnya seperti Classical Swine Fever (Hog Cholera), Pig Respiratory and Reproductive Syndrome (PRRS), Erysipelas, Salmonellosis, Aujeszky (atau pseudorabies) terutama pada babi yang lebih muda, Pasteurellosis dan penyakit babi yang menyebabkan septikemia lainnya. Gejala penyakit Hog Cholera di lapang sering mirip dengan penyakit ASF, sehingga pemeriksaan laboratorium sangat dibutuhkan untuk membedakan dengan penyakit tersebut (SanchezVizcano et al. 2015). 


\section{Pemeriksaan laboratorium}

Deteksi antibodi terhadap ASF dapat dilakukan dengan uji serologi seperti uji ELISA, Hemaglunisasi Inhibisi dan Immunodot blot (Balyshev et al. 2018; Zhao et al. 2019). Sedangkan uji deteksi virus ASF dilakukan dengan uji fluorescent antibodi (DFA) dan real time q-PCR (Balyshev et al. 2018; MazurPanasiuk \& Woźniakowski 2019a) dan konvensional PCR. Real time PCR dan ELISA merupakan diagnosis baku dan paling sering digunakan (Chenais et al. 2017).

Sampel yang dapat dikoleksi diantaranya serum untuk pemeriksaan serologi (Chenais et al. 2017) dan untuk uji virologik berupa organ seperti limpa, hati, tonsil, ginjal, limfoglandula, jantung dan paru atau darah dalam EDTA, swab nasal dan swab rektal (Sanchez-Vizcano et al. 2015; Beltran-Alcrudo et al. 2017).

Untuk pengujian RT-PCR, dapat menggunakan sampel seperti tanah yang telah terkontaminasi cairan tubuh babi atau tempat pemotongan babi secara tradisional, air minum babi, sisa makanan atau tempat pembuangan feses/manure (Chenais et al. 2017).

Isolasi virus ASF dapat dilakukan pada Swine pulmonary alveolar macrophages (PAMs) (MazurPanasiuk \& Woźniakowski 2019a: Zhao et al. 2019) atau sel primer dari Swine leucocyte (SL) dan transplantable hybrid cell line (A4C2/9k) (Balyshev et al. 2017). Selain itu, jaringan kultur lestari Pig Kidney (PK) juga dapat digunakan untuk mengembangkan virus ASF (Cabezon et al. 2017). Namun penggunaan sel lestari PK tidak sensitif untuk isolasi ASF asal sampel lapang. Titer virus diperoleh dari sampel darah lebih tinggi dibanding sampel organ (Chenais et al. 2017; Balyshev et al. 2018). Virus ASF menyebabkan cythopathic effect (CPE) pada sel dan mempunyai daya hemadsorption (Reis et al. 2016; Zhao et al. 2019)

\section{Situasi ASF di dunia}

Penyakit ASF pertama kali ditemukan di AfrikaKenya pada tahun 1921, yang kemudian menyebar di sebagian besar sub-Sahara Afrika termasuk di Pulau Madagaskar, sehingga penyakit ini menjadi endemik di Afrika pada babi (FAO 2018).

Situasi ASF di Asia, sejak kejadian ASF pertama kali di Cina Agustus 2018 (Zhao et al. 2019), penyakit ini telah menyebar ke Mongolia (Januari 2019), Vietnam (Februari 2019), Kamboja (Maret 2019), Hongkong dan Korea Utara (Mei 2019), Laos (Juni 2019) dan kemudian ke Myanmar (Agustus 2019), Philipina, Korea Selatan dan Timor Leste (September 2019) (OIE 2019). Indonesia masih dinyatakan bebas ASF hingga bulan September 2019, namun pada bulan Oktober 2019 dilaporkan banyak kematian pada babi di Sumatera Utara. Investigasi telah dilakukan oleh Balai
Besar Penelitian Veteriner (BBLitvet) dan telah berhasil mendeteksi virus ASF menggunakan PCR. Surat Keputusan Menteri Pertanian Republik Indonesia nomor 820/KPTS/PK.320?M/12/2019 mengumumkan bahwa infeksi ASF telah berada di Sumatera Utara.

Virus ASF menunjukkan tingkat evolusi yang tinggi dan menyebar sejalan dengan waktu, tanpa tanda-tanda penurunanan hingga saat ini. Hal ini sejalan dengan meningkatnya populasi babi dan tingginya lalu lintas perdagangan babi antar negara yang menyebabkan virus tetap bersirkulasi dan terpelihara di Euroasia dan Afrika (Alkhamis et al. 2018)

Melihat dampak yang ditimbulkan penyakit ASF demikian besar, maka pemerintah Indonesia melalui Kementerian Pertanian harus melakukan penanganan dan pencegahan penyebaran ASF ke daerah lainnya, agar peluang perdagangan ternak dan produk ternak internasional tidak terhambat, serta kesehatan ternak terutama ternak babi tetap terjaga melalui monitoring dan surveylan yang berkesinambungan serta melibatkan semua stake holder terkait.

\section{PENCEGAHAN PENYAKIT}

Pencegahan dan kontrol penyakit ASF belum dapat dilakukan dengan vaksinasi maupun obat antiviral karena belum tersedia secara komersial. Bagi negara yang masih dinyatakan bebas ASF, maka beberapa pencegahan yang dapat dilakukan antara lain peningkatan karantina dan biosekuriti yang ketat, membatasi lalu lintas babi dan pengurangan populasi ternak babi yang sakit dan terpapar. Disamping penerapan biosekuriti yang baik, mengurangi kontak dengan pakan/ alat yang tercemar seperti penggunaan swill feeding sebagai pakan ternak babi dan pengolahan limbah pesawat, serta pengetatan barang bawaan penumpang pesawat dan kapal laut perlu dilakukan. Walaupun di Indonesia tidak mudah untuk menerapkan kebijakan tersebut karena sebagian besar peternak babi di Indonesia merupakan peternak tradisional yang masih banyak menggunakan swill feeding sebagai pakan ternak. Tentunya pendekatan ini perlu didukung dengan pengawasan lalu lintas ternak babi, pembersihan dan disinfeksi kandang dan dukungan penuh dari pemerintah.

Beberapa penelitian tentang vaksin ASF telah dilakukan dalam dekade terakhir, namun hingga saat ini belum diperoleh vaksin yang efektif dan aman, bahkan penggunaan vaksin inaktif dinilai gagal melindung hewan (Reis et al. 2016). Beberapa vaksin ASF yang telah dikembangkan antara lain vaksin inaktif, vaksin live attenuated, vaksin sub unit, vaksin DNA. Vaksin inaktif menghasilkan respon antibodi namun tidak protektif (Titov et al. 2017). 
Vaksin inaktif dinilai cukup aman namun tidak memberikan proteksi pada babi (Reis et al. 2016). Pengembangan vaksin atenuasi dapat memberikan respon antibodi yang baik dan dapat memberikan proteksi pada isolat virus ASF yang homolog dan proteksi silang dengan beberapa strain virus ASF lainnya dalam satu genotipe, namun masih perlu dikaji ulang tingkat keamanan dari vaksin tersebut (King et al. 2011; Mulumba-Mfumu et al. 2016). Penelitian terakhir menunjukkan bahwa vaksin atenuasi dan vaksi hidup yang telah dimodifikasi hanya memberikan proteksi pada virus yang homolog, tetapi tidak terhadap virus yang heterolog (Reis et al. 2016; Kolbasov et al. 2014). Hal ini telah dibuktikan oleh Rock (2017) dan Gaudreault \& Richt (2019) pada uji tantang, sehingga vaksin ini masih belum dapat memberikan perlindungan optimal untuk diterapkan di lapang.

Penggunaan vaksin hidup yang telah dilemahkan dapat menggertak antibodi terhadap ASF dengan baik, namun virus ASF yang telah dilemahkan tersebut masih dapat bertahan dalam tubuh selama beberapa minggu dan dapat menjadi virulen (Titov et al. 2017), Disamping itu, vaksin hidup yang dilemahkan dapat menyebabkan efek samping seperti lesi yang bersifat kronis, demam, ptechie, pembengkakan sendi atau pneumonia (Gaudreault \& Richt 2019; King et al. 2011; Titov et al. 2017) dan virus ASF masih dapat ditemukan dalam jaringan beberapa hewan yang divaksinasi (Sanchez-Vizcano et al. 2015). Oleh karena itu penggunaan vaksin hidup yang telah dilemahkan masih sangat terbatas dan masih menjadi pertimbangan lebih lanjut.

Meskipun virus ASF hanya memliliki satu serotipe namun virus ini memiliki variasi genetik yang tinggi diantara isolat virus ASF yang ada terutama adanya perbedaan ukuran genom, perubahan jumlah dan urutan multigenik (Nix et al. 2006). Hal ini mungkin dapat disebabkan karena virus ASF bersifat macrophage tropic, sehingga dapat memanipulasi kekebalan bawaan dan memiliki respon adaptasi dengan memodulasi fungsi makrofag yang dapat mencegah pengembangan sistem pertahanan imun tubuh dan menghambat interferon tipe 1 (Dixon et al. 2013). Nefedeva et al. (2019) telah melakukan evaluasi keragaman protein imunomodulator dan dinamika evolusi virus ASF untuk memprediksi kemungkinan peran gen A238L, I329L dan Dp71L terhadap virulensinya sehingga variabilitas protein imunomodulator 5EL, I14L dan K11L dapat mengindentifikasi situs target genom virus ASF dan potensi untuk pengembangan vaksin.

Pengembangan vaksin sub unit melalui rekayasa genetika dinilai aman, namun hasilnya tidak memuaskan karena hanya memberikan proteksi pada sebagian kecil ternak babi. Vaksin DNA kemudian dikembangkan, tetapi hasilnya juga kurang memuaskan karena kurang protektif (Murgia et al. 2019), demikian pula dengan vaksin virus-vectored ASF. Ketiga jenis vaksin ini dinilai kurang protektif dan tidak konsisten. Ketidak konsistenan vaksin tersebut tergantung dari beberapa faktor, diantaranya tipe vaksin yang digunakan, strategi vaksinasi, antigen yang digunakan atau respon imun yang dihasilkan (Gaudreault \& Richt 2019). Oleh karena itu, akhir-akhir ini telah dikembangkan vaksin dengan menggunakan delesi gen virulen. Secara percobaan vaksin delesi gen ini dapat diharapkan, namun masih memerlukan penelitian lebih lanjut (Murgia et al. 2019). Penelitian O'donnell et al. (2016) melaporkan delesi gen 9GL dan MGF 360/505 pada virus virulen ASF strain Georgia 2007 akan melemahkan virulensi ASF tersebut, namun bila dibuat vaksin tidak memberikan proteksi pada uji tantang. Kemudian dikembangkan vaksin delesi dari 8 gen di Eropa, masih memberikan hasil yang kurang memuaskan. Lebih lanjut di China, delesi dilakukan pada 11 gen virulen virus ASF, hasilnya masih dalam penelitian lebih lanjut (Sanchez-Vizcano, pers.com).

\section{Biosekuriti}

Tindakan biosekuriti yang ketat dapat membantu mencegah atau memperlambat penyebaran ASF, sehingga peternak, produsen dan dokter hewan harus mematuhi biosekuriti yang ketat. Prosedur standar masuk ke peternakan harus menggunakan sepatu dan baju kandang yang baru agar fomit yang menempel pada pakaian atau sepatu tidak terbawa ke tempat lain yang dapat menyebarkan infeksi ASF ke peternak lainnya. Kendaraan pengangkut babi harus didesinfeksi sebelum memasuki area peternakan.

Penerapan biosekuriti ini sangat membantu dalam mengurangi penyebaran infeksi ASF, namun di peternakan babi tradisional, penerapan biosekuriti ini sangat sulit dilakukan karena babi tidak dipelihara di kandang, tapi lebih banyak di lepas pada siang hari dan sore hari kembali ke kandang. Hal ini juga terungkap dalam laporan Dione et al. (2014) dan Nantima et al. (2015) yang menyatakan bahwa biosekuriti peternakan di Uganda dan negara Afrika lainnya sulit untuk diterapkan di perternakan babi rakyat, apalagi bila sistem pemeliharaannya ekstensif. Kondisi ini berbeda dengan industri peternakan babi skala besar, yang telah menerapkan biosekuriti yang ketat (Chenais et al. 2017; Penrith et al. 2013).

Penerapan biosekuriti pada peternak rakyat/tradisional di Indonesia juga sangat sulit diterapkan mengingat lebih dari 2 juta (25\%) dari populasi babi merupakan peternak kecil yang dipelihara secara intensif atau semi ekstensif dimana babi dilepas pagi hari dan dikandangkan sore hari. Pada beberapa daerah tertentu babi yang sakit dilepas sehingga berkeliaran kemana-mana yang akhirnya 
dapat menyebarkan penyakit ke babi disekitarnya dan atau daerah sekitarnya. Lebih lanjut, populasi babi liar di Indonesia masih sulit untuk diidentifikasi dan di monitoring serta sering berkeliaran ke rumah penduduk untuk mencari pakan yang kemungkinan kontak dengan babi rakyat sangat besar sehingga dapat menularkan penyakit ASF. Ditinjau dari aspek personal, peternak babi yang babinya sakit sering berinteraksi dengan peternak babi lainnya untuk berdiskusi masalah penyakit babi yang sedang dihadapinya. Oleh karena itu sosialisasi penyakit ASF melalui komunikasi, informasi dan edukasi (KIE) pada masyarakat tentang penyakit ASF, cara penularan dan pentingnya mencegah penularan ASF perlu dilakukan.

Peternak babi skala besar dan industri babi biasanya telah menerapkan sistim biosekuriti yang sangat ketat, terlebih saat adanya kasus ASF di Indonesia. Biosekuriti tersebut seperti melarang tamu, dokter hewan masuk ke peternakan, terlebih lagi setelah masuk ke peternakan lain. Penggunaan sepatu boot, pakaian terpisah, mendesinfeksi sepatu dan kendaraan diberlakukan pada pekerja kandang, sistem pengelompokan kandang babi berdasarkan umur dan kandang isolasi tersedia dan desinfeksi sepatu, gerobak dan peralatan lainnya saat masuk dan keluar kandang.

\section{Pengolahan limbah}

Pada kasus terjadinya wabah dalam satu peternakan, maka pengolahan limbah yang tepat perlu diterapkan agar penyebaran ASF dapat diminimalkan. Limbah tersebut antara lain sisa makanan, feses hewan, urin dan keranjang pengangkut babi. Demikian pula dengan sisa pakan, pelindung pribadi dan peralatan yang terkontaminasi, yang tidak dapat dibersihkan dan didesinfeksi. Tempat pakan, pakaian, sepatu boot dan keranjang babi serta kandang yang akan digunakan kembali dapat dilakukan dekontaminasi dengan menyemprotkan disinfektan seperti virkon atau larutan pemutih.

Lebih lanjut, swill feeding atau sisa makanan dan barang sitaan yang mengandung babi dari bandara, restoran atau pelabuhan yang berasal dari negara tertular, tidak boleh diberikan pada ternak babi, tetapi harus dimusnahkan di tempat sehingga tidak menyebar.

\section{AFRICAN SWINE FEVER DI INDONESIA}

Periode bulan September 2019, telah dilaporkan banyaknya babi sakit di Provinsi Sumatera Utara dengan gejala mirip dengan ASF. Kematian babi yang sangat besar hingga mencapai 40.000 ekor di peternakan tradisional/rakyat telah dilaporkan oleh Dinas Peternakan Provinsi Sumatera Utara, dengan gejala klinis seperti demam; petechiae di daerah telinga, kaki bagian dalam, abdomen, anoreksia, tidak nafsu makan, lesu dan lemas dan berakhir dengan kematian. Hasil identifikasi BBlitvet yang dilakukan pada bulan November 2019 menunjukkan bahwa kematian babi disebabkan oleh virus ASF (Dharmayanti, pers com.). Pada bulan Desember 2019, Indonesia melalui Keputusan Menteri Pertanian Republik Indonesia telah menyatakan wabah ASF pada beberapa kabupaten/kota di Provinsi Sumatera Utara.

\section{BAGAIMANA ASF DAPAT MASUK KE INDONESIA?}

Jalur masuknya ASF seperti dilaporkan di Uni Eropa, terutama melalui truk pengangkut babi, swill feeding dari pesawat dan kapal laut (Mur et al. 2012), meskipun faktor lainnya seperti wisatawan, pengungsi dan pekerja asing dapat berperan (Satran et al. 2017). Beberapa kemungkinan ASF masuk ke Indonesia diantaranya melalui swill feeding dari pesawat asal negara tertular atau dari barang tentengan/sitaan penumpang yang tidak habis dimakan yang telah tercemar ASF dan dimanfaatkan oleh peternak sebagai pakan babi karena harganya relatif sangat murah dibandingkan pakan komersial seperti telah dijelaskan sebelumnya.

Berdasarkan hasil pengamatan dan wawancara terhadap peternak di lapang, menunjukkan bahwa penggunaan swill feeding di Indonesia sering dilakukan oleh peternak babi tradisional karena biaya pakan yang murah, meskipun efektivitas pertumbuhan babi yang diberikan swill feeding ini tergolong lambat dan tidak efisien. Sebagian peternak langsung memberikan swill feeding ke ternak babi tanpa melakukan pengolahan seperti pemanasan. Selain sebagai pakan ternak, swill feeding juga memberikan insentif yang besar bagi pengumpul atau pengepul swill feeding karena mempunyai nilai jual dan peminat yang banyak.

Kemungkinan lain masuknya ASF di Indonesia adalah sisa makanan dari hotel yang dibawa oleh wisatawan dari negara tertular mengingat banyak sekali wisatawan dari negara tertular seperti China, Vietnam, Thailand yang berkunjung atau bekerja di Indonesia dan biasanya membawa makanan dari negara asal seperti sosis, ham, daging asap dan produk daging babi lainnya. Makanan sisa tersebut biasanya dibuang tanpa pengolahan lebih lanjut yang pada akhirnya sampai ke tangan pengumpul untuk dijual sebagai pakan ternak. Untuk itu peran karantina untuk menguji bahan makanan yang mengandung produk daging babi asal negara tertular sangat penting. Hasil penelitian yang dilakukan BBLitvet menunjukkan bahwa barang bawaan penumpang yang terdiri dari sosis daging babi atau daging asap asal negara tertular, terdeteksi virus ASF dengan uji PCR (Sendow. data tidak dipublikasikan). 
Masuknya ASF melalui fomit, seperti sepatu wisatawan dari negara tertular yang pernah kontak dengan babi terinfeksi ASF juga merupakan salah satu jalur penularan penyakit. Negara Australia membuat peraturan bagi semua penumpang penerbangan untuk mendeklarasi barang bawaan makanan dan menanyakan pernah mengunjungi peternakan atau kontak dengan hewan. Cara ini cukup efektif untuk mencegah masuknya ASF ke negara tersebut, dengan sangsi hukum yang ketat.

Masuknya infeksi ASF dalam suatu peternakan maka menyebabkan penyebaran penyakit sangat cepat ke daerah lain dan sulit dicegah, kecuali dengan melakukan pemusnahan babi yang sakit dan dan babi lainnya yang pernah terpapar/kontak dengan babi sakit. Pemerintah perlu menyediakan dana kompensasi untuk pemusnahan babi terinfeksi sebelum penyakit meluas ke peternakan lainnya. Kurangnya wawasan dan pengetahuan peternak dan masyarakat, tentang penyakit ASF, gejala klinis, proses penyebaran dan cara penanganan penyakit, merupakan salah satu faktor menyebarnya penyakit ASF. Penularan dapat juga terjadi melalui alat angkut/truk dan keranjang babi yang terinfeksi tanpa melalui desinfeksi. Tanggapan pemerintah yang cepat melalui karantina yang ketat, penutupan terbatas lalu lintas babi, pengolahan swill feeding yang baik sangat diperlukan untuk mencegah penyebaran infeksi ASF ke daerah lain di Indonesia. Kerjasama lintas sektor termasuk otoritas bandara/ Kementerian Perhubungan, Kementerian Pertanian, Kementerian Pariwisata, pengusaha industri babi dan semua stake holder terkait.

\section{KESIMPULAN}

Penyakit ASF sebagai penyakit notifiable diseases, sangat ditakuti oleh peternak babi karena selain tingkat penularan dan kematiannya tinggi, juga dapat menghambat komoditas ekspor sehingga ikut berdampak pada perekonomian suatu negara. Penyakit ASF telah masuk ke Indonesia yang diduga melalui produk babi yang dibawa dari daerah negara tertular. Pemberantasan penyakit ASF di Indonesia sulit dilakukan karena telah menyebar, sedangkan penggunaan vaksin yang efektif dan aman masih belum tersedia. Untuk itu pemerintah dan semua stake holder terkait perlu berpartisipasi melalui penerapan biosekuriti yang ketat, menyediakan fasilitas diagnosis penyakit yang cepat dan akurat. Selain itu, perlu penguatan surveilans dan monitoring transportasi babi hidup dan produknya, pelarangan barang bawaan penumpang yang mengandung daging babi dari negara tertular dan melakukan advokasi bahaya penggunaan swill feed sebagai pakan ternak.

\section{DAFTAR PUSTAKA}

Abworo EO, Onzere C, Amimo JO, Riitho V, Mwangi W, Davies J, Blome S, Bishop RP. 2017. Detection of African swine fever virus in the tissues of asymptomatic pigs in smallholder farming systems along the Kenya-Uganda border: Implications for transmission in endemic areas and ASF surveillance in East Africa. J General Virol. 98:1806-1814.

Alkhamis MA, Gallardo C, Jurado C, Soler A, Arias M, SaÂnchez-VizcaõÂno JM. 2018. Phylodynamics and evolutionary epidemiology of African swine fever p72-CVR genes in Eurasia and Africa. PLoS ONE. 13:e0192565.

Balyshev VM, Vlasov ME, Imatdinov AR, Titov I, Morgunov S, Malogolovkin AS. 2018. Biological properties and molecular-genetic characteristics of African Swine Fever virus isolated in various regions of Russia in 2016-2017. Russ Agric Sci. 44:469-473.

Beltran-Alcrudo DB, Falco JR, Raizman E, Dietze K. 2019. Transboundary spread of pig diseases: the role of international trade and travel. BMC Vet Res. 15:1-14.

Beltrán-Alcrudo D, Arias M, Gallardo C, Kramer S, Penrith ML. 2017. African swine fever: detection and diagnosis - A manual for veterinarians. FAO Animal Production and Health Manual No. 19. Rome (Italy): Food and Agriculture Organization of the United Nations.

Boinas FS, Wilson AJ, Hutchings GH, Martins C, Dixon LJ 2011. The persistence of African Swine Fever Virus in field-infected Ornithodoros erraticus during the ASF endemic period in Portugal. PLoS ONE. 6:e20383.

Cabezón O, Muñoz-González S, Colom-Cadena A, PérezSimó M, Rosell R, Lavín S, Marco I, Fraile L, de la Riva PM, Rodríguez F, Domínguez J, Ganges L. 2017. African swine fever virus infection in Classical swine fever subclinically infected wild boars. BMC Vet Res. 13:227.

Chenais E, Sternberg-Lewerin S, Boqvist S, Liu L, LeBlanc N, Aliro T, Masembe C, Ståhl K. 2017. African swine fever outbreak on a medium-sized farm in Uganda: Biosecurity breaches and within-farm virus contamination. Trop Anim Health Prod. 49:337-346.

Chenais E, Depner K, Guberti V, Dietze K, Viltrop A, Ståhl K. 2019. Epidemiological considerations on African swine fever in Europe 2014-2018. Porc Heal Manag. 5:1-10.

Dione M, Ouma EA, Roesel K, Kungu J, Lule P, Pezo D. 2014. Participatory assessment of animal health and husbandrypractices in smallholder pig production systems in three highpoverty districts in Uganda. Preventive Vet Med. 117:565-576.

Dixon LK, Chapman DAG, Netherton CL, Upton C. 2013. African swine fever virus replication and genomics. Virus Res. 173:3-14. 
[FAO] Food and Agriculture Organization of the United Nations. 2018. African Swine Fever threatens people 's Republic of China: A rapid risk assessment of ASF introduction [Internet]: [accessed 2nd December 2019]. Available from: http://www.fao.org/3/ I8805EN/i8805en.pdf

Gaudreault NN, Richt JA. 2019. Sub-unit vaccine approaches for African Swine Fever virus. Vaccines. 7:1-20.

King K, Chapman D, Argilaguet JM, Fishbourne E, Hutet E, Cariolet R, Hutchings G, Oura CA, Netherton CL, Moffat K, Taylor G, Le Potier, MF, Dixon LK, Takamatsu HH. 2011. Protection of European domestic pigs from virulent African isolates of African swine fever virus by experimental immunisation. Vaccine. 29:4593-4600.

Kipanyula MJ, Nong’ona SW. 2017. Variations in clinical presentation and anatomical distribution of gross lesions of African swine fever in domestic pigs in the southern highlands of Tanzania: a field experience. Trop Anim Health Prod. 49:303-310.

Kolbasov DV, Balyshev VM, Sereda AD. 2014. Overall results of the development of African swine fever live vaccines. Veterinariya. 8:3-8.

Malogolovkin A, Burmakina G, Titov I, Sereda A, Gogin A, Baryshnikova E, Kolbasov D. 2015. Comparative analysis of African swine fever virus genotypes and serogroups. Emerg Infect Dis. 21:312-315.

Mazur-Panasiuk N, Woźniakowski G. 2019a. The unique genetic variation within the $0174 \mathrm{~L}$ gene of Polish strains of African swine fever virus facilitates tracking virus origin. Arch Vir. 164:1667-1672.

Mazur-Panasiuk N, Żmudzki J, Woźniakowski G. 2019b. African swine fever virus - persistence in different environmental conditions and the possibility of its indirect transmission. J Vet Res. 63:303-310.

Montgomery E. 1921. On a form of swine fever occurring in British East Africa (Kenya colony), J Comparative Path Therapeu. 24:159-191.

Mulumba-Mfumu LK, Goatley LC, Saegerman C, Takamatsu HH, Dixon LK. 2016. Immunization of African indigenous pigs with attenuated genotype I African swine fever virus OURT88/3 induces protection against challenge with virulent strains of genotype I. Transbound Emerg Dis. 63:e323-7.

Mur L, Atzeni M, Martinez-Lopez B, Feliziani F, Rolesu S, Sanchez-Vizcaino JM. 2016. Thirty-five-year presence of African Swine Fever in Sardinia: History, evolution and risk factors for disease maintenance. Transbound Emerg Dis. 63:e16577.

Mur L, Martinez-Lopez B, Sanchez-Vizcaino JM. 2012. Risk of African swine fever introduction into the European Union through transport-associated routes: returning trucks and waste from international ships and planes. BMC Vet. Res. 8:1-12.

Murgia MV, Mogler M, Certoma A, Green D, Monaghan P, Williams DT, Raymond R, Rowland R, Gaudreault
NN. 2019. Evaluation of an African swine fever (ASF) vaccine strategy incorporating priming with an alphavirusexpressed antigen followed by boosting with attenuated ASF virus. Arch Vir. 164:359-370.

Nantima N, Ocaido M, Ouma E, Davies J, Dione M, Okoth E, Mugisha A, Bishop R. 2015. Risk factors associated with occurrence of African swine fever outbreaks in smallholder pig farms in four districts along the Uganda-Kenya border, Trop Anim Health Prod. 47:589-595.

Nefedeva MV, Titov IA, Mima KA, Malogolovkin AS. 2019. Analysis of the African Swine Fever virus immunomodulatory proteins. Mol Gen Microbiol Vir. 3:42-49.

Nix RJ, Gallardo C, Hutchings G, Blanco E, Dixon LK. 2006. Molecular epidemiology of African swine fever virus studied by analysis of four variable genome regions. Arch Virol. 151:2475-2494.

O’Donnell V, Holinka LG, Sanford B, Krug PW, Carlson J, Pacheco JM, Reese B, Risatti GR, Gladue DP, Borca MV. 2016. African swine fever virus Georgia isolate harboring deletions of 9GL and MGF360/505 genes is highly attenuated in swine but does not confer protection against parental virus challenge. Virus Res. 221:8-14.

[OIE] Organizacion Internacional de Epizootias. 2017. WAHID database, Disease information [Internet]: [accessed 2nd December 2019]. Available from: http://web.oie.int/wahis/public.php?page=disease_im mediate_summary.

Olesen AS, Lohse L, Boklund A, Halasa T, Gallardo C, Pejsak Z, Belsham GJ, Rasmussen TB, Botner A. 2017. Transmission of African swine fever virus from infected pigs by direct contact and aerosol routes. Vet Microbiol. 211:92-102.

Penrith ML, Vosloo W, Jori F, Basto AD. 2013. African swine fever virus eradication in Africa. Virus Res. $173: 228-246$

Reis AL, Abrams CC, Goatley LC, Netherton C, Chapman DG, Sanchez-Cordon P. Dixon LK. 2016. Deletion of African swine fever virus interferon inhibitors from the genome of a virulent isolate reduces virulence in domestic pigs and induces a protective response. Vaccine. 34:4698-4705.

Rock DL. 2017. Challenges for African swine fever vaccine development-"perhaps the end of the beginning". Vet Microbiol. 206: 52-58.

Rodriguez JM, Moreno LT, Alejo A, Lacasta A, Rodriguez F, Salas ML. 2015. Genome sequence of African swine fever virus BA71, the virulent parental strain of the nonpathogenic and tissue-culture adapted BA71V. PLoS One. 10:p.e0142889.

Sanchez-Vizcano JM, Mur L, Gomez-Villamandos JC, Carrasco JL. 2015. An update on the epidemiology and pathology of African swine fever. J Comp Pathol. 15:9-21. 
WARTAZOA Vol. 30 No. 1 Th. 2020 Hlm. 15-24

Siamupa C, Saasa N, Phiri AM. 2017. Contribution of market value chain to the control of African swine fever in Zambia. Trop Anim Health Prod. 50:177-185.

Titov I, Burmakina G, Morgunov Y, Morgunov S, Koltsov A, Malogolovkin A, Kolbasov D. 2017. Virulent strain of African swine fever virus eclipses its attenuated derivative after challenge. Arch Virol. 162:30813088.

Zhao D, Liu R, Zhang X, Li F, Wang J, Zhang J, Liu X, Wang L, Zhang J, Wu X, Guan Y, Chen W, Wang X, He X, Bu Z.2019. Replication and virulence in pigs of the first African swine fever virus isolated in China. Emerging Microbes Infect. 8:438-447. 